\title{
Barium, Calcium and Sodium, Cyanide, Phosphate and Sulphate Contents of Groundwater in Some Ika Communities of Delta State, Nigeria
}

\author{
Hector H. Oyem ${ }^{1,2}$, Ifeanyi M. Oyem ${ }^{1}$, Esther N. Obiwulu ${ }^{1}$ \\ ${ }^{1}$ Department of Integrated Science, College of Education, Agbor, Nigeria \\ ${ }^{2}$ School of Chemistry, Newcastle University, Newcastle Upon Tyne, UK \\ Email:hectoroyem@yahoo.co.uk
}

How to cite this paper: Oyem, H.H., Oyem, I.M. and Obiwulu, E.N. (2017) Barium, Calcium and Sodium, Cyanide, Phosphate and Sulphate Contents of Groundwater in Some Ika Communities of Delta State, Nigeria. Journal of Geoscience and Environment Protection, 5, 89-98. https://doi.org/10.4236/gep.2017.58009

Received: June 4, 2017

Accepted: July 31, 2017

Published: August, 3, 2017

Copyright $\odot 2017$ by authors and Scientific Research Publishing Inc. This work is licensed under the Creative Commons Attribution International License (CC BY 4.0).

http://creativecommons.org/licenses/by/4.0/

\begin{abstract}
Barium, calcium, sodium, cyanide, phosphate and sulphate and contents of groundwater in Boji-Boji (BB) area and suburbs of Ika land, Delta State, Nigeria were studied. Groundwater is the predominant source of water for inhabitants of these communities without any form of treatment. 55 borehole water sites spread within these five sample sub-areas. The metal ions were analyzed using Solar Unicam flame Atomic Absorption Spectrophotometer. Sulphate, phosphate, and cyanide contents were determined by colorimetric method. Results indicate the presence of sodium, calcium, sulphate, and phosphate. However, barium and cyanide were below detection limit. Secondly, there was a relatively higher proportion of calcium and sulphate than sodium and phosphate in its aquifer. Thirdly, a mean ratio value of 0.018 and 0.158 was observed for the ratios of $\mathrm{Na}^{+} / \mathrm{Ca}^{2+}$ and $\mathrm{PO}_{4}^{3-} / \mathrm{SO}_{4}^{2-}$ respectively. Fourthly, sodium showed good correlation with all the other parameters. Finally, nearly all the studied parameters have concentrations below the maximum contaminant levels of the World Health Organization (WHO), invariably inferring that the water is wholesome with respect to the analytes. However, concern still remains from a health point of view on the sodium concentrations in many sample areas.
\end{abstract}

\section{Keywords}

Ground Water, Sodium, Calcium, Sulphate, and Phosphate

\section{Introduction}

Water is an invaluable resource to man and living things-essential for the sus- 
tenance of life on earth as exemplified by its diversified uses (drinking, cooking, washing, irrigation, farming etc.) [1]. It is the most abundant chemical substance on earth, covering about two-third of its surface [2] and supporting all forms of plant and animal life [3]. However, the fresh water available is between $0.3 \%$ $0.5 \%$ of the total water on earth [4].

Without clean water, people's health and livelihood can be severely affected [5]. As a result of its unique chemical properties, water is able to dissolve, absorb, adsorb, or suspend many different compounds [6]. Thus in nature, water is not pure as it acquires contaminants from its surrounding [7]. One of the important issues of today is groundwater contamination [8]. Global water resources are imperiled not only by over-exploitation but also by ecological degradation [9] from the geology and geochemistry of the environment [10] [11].

Ground water is the water that exists underground. Although it can be present as underground lakes beneath the Earth's surface, it commonly lies in the tiny spaces between grains of sand or bits of fractured rock [12]. It is part of precipitation that seeps down through the soil until it reaches rock material saturated with water [13]. When rain falls, the water does not stop moving, some sink into the ground [14]. Groundwater can be found almost everywhere, and are replenished, or recharged by rain and snow melt [14].

The quality of drinking water and its availability for drinking, industrial, and agricultural purposes is a major and crucial factor for the sustainable development of a society. The contamination of water is directly proportional to the degree of environmental degradation [15]. Evaluating groundwater quality is essential for the development of civilization and to establish database for planning and evolving strategies for managing this vital resource [5] [15]. The importance of not just knowing the quality of (ground) water but to protect it from contamination was further stressed on [5].

According to [16], between the very wide diversity of contaminants affecting water resources, heavy metals receive particular rave attention considering their strong toxicity even at low concentrations. However, for the purpose of contributing to available data and thus widening the scope of knowledge with regards to the quality of groundwater in the study area, this paper focuses on non-heavy metal (secondary) contaminants and some anions as well with particular reference to sodium, calcium, barium, tetraoxosulphate (VI) ion (sulphate), tetraoxophosphate (V) ion (phosphate), and cyanide.

\section{Study Area}

The study area (Agbor/Owa town commonly referred to as Boji-Boji (BB)) found within longitudes $6^{\circ} \mathrm{E}-6^{\circ} 30^{\prime} \mathrm{E}$ and latitudes $6^{\circ} \mathrm{N}-6^{\circ} 30^{\prime} \mathrm{N}$, was mapped out in to five (5) sub-areas of Agbor Obi, Boji-Boji Agbor, Boji-Boji Owa, Alihame, and Owa Alero. The latter two areas (Alihame and Owa Alero) being classified as suburban towns for the purpose of this exercise on the basis of socio-economic stratification and population density. Both Boji-Boji centers of 
Agbor/Owa comprise essentially of higher-level school teachers/lecturers, medical and health workers, a myriad of religious organizations and clergy, some government ministry staff, sundry small scale business workers/traders, bank and security staff, legal practitioners and main-stay politicians. The other areas are more predominantly farmers, various artisans and lower-level school teachers and schools (Figure 1).

The geology of the area is mainly of the recent tertiary sedimentary sand stone, with the Bini formation as a typical example. This indicates a lee way for easy passage of leachate through to the ground water in the underlying reservoir. The climate of the study area exhibits the characteristics of a sub-equatorial climate with an annual mean air temperature of $27.0^{\circ} \mathrm{C}$ [17]. The rainfall pattern is that of double peaks or maxima with mean annual rainfall of $2255 \mathrm{~mm}$. Mean relative humidity is $81 \%$, sunshine is $5.6 \mathrm{hr} /$ day and the soil type is red-yellow ferralsols [18].

\section{Materials and Methods}

A total of 55 borehole water sources were sampled in all from these areas, with an average of about 15 per area for Agbor Obi, Boji-Boji Agbor and Owa areas, and five (5) for Owa Alero and Alihame communities on the basis of fewer wells per unit area. Borehole water sample sites were randomly spaced and samples collected in clean new $300 \mathrm{ml}$ sterile bottles [19] filled to the brim, then preserved by cooling in dark ice bag [20] before taken to the laboratory for analysis immediately after sampling without filtration and acidification [21].

\section{A MAP OF DELTA STATE SHOWING SELECTED TOWNS IN IKA ETHNIC AREA}

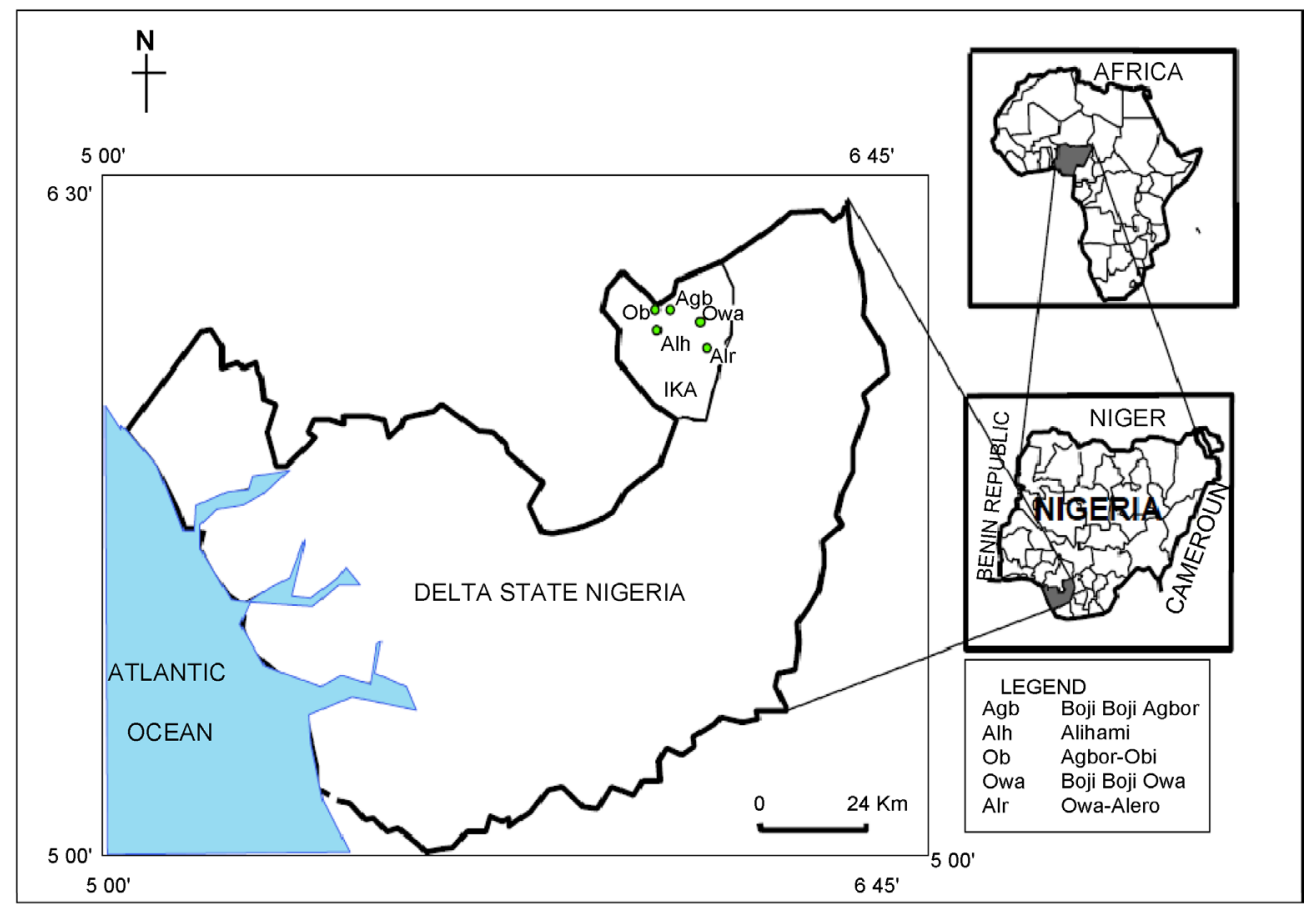

Source: Department of Land Information systems, Ministry of Lands Surveys \& Urban Development, Asaba, Delta State

Figure 1. Map of delta state, Nigeria showing Ika land and the sample sub-areas. 
At the laboratory, the samples were carefully transferred in to a clean and larger container of $4 \mathrm{~L}$ in capacity previously sterilized, and a composite sample [22] thus formed per sample area. Samples were collected on different days and in the mornings of the month of August 2013 in the peak of the rainy season. The composite sample was then analyzed for metallic ions concentrations using Solar Unicam flame Atomic Absorption Spectrophotometer model 969 series [23] [24]. Anionic components were analyzed by colorimetric method using visible spectrophotometer model 712 [24].

All instruments carefully and properly calibrated prior to analyses.

\section{Results and Discussion}

\subsection{Sodium}

Results of sodium analysis in the sample areas are presented in Table 1. The minimum value of $0.18 \mathrm{mg} / \mathrm{L}$ (14.2\%) is observed for Owa-Alero area, while Boji-Boji Agbor area recorded the maximum value of all at $0.35 \mathrm{mg} / \mathrm{L}$, representing 27.6\% approximately (Table 2). World Health Organization (WHO) and Nigerian water quality standards give a guideline value of $200 \mathrm{mg} / \mathrm{L}$ for sodium in drinking water. However, results from Table 1 suggests an average sodium content of $0.25 \mathrm{mg} / \mathrm{L}$. Sodium ( $\mathrm{Na}$ ) is an essential element required for normal body function including nerve impulse transmission, fluid regulation, and muscle contraction and relaxation [25] [26]. However, in excess amounts, sodium increases

Table 1. Concentrations of detected chemical parameters under analysis in the study area.

\begin{tabular}{ccccccc}
\hline $\begin{array}{c}\text { Sample } \\
\text { Area }\end{array}$ & \multicolumn{2}{c}{$\mathrm{Na}^{+}(\mathrm{mg} / \mathrm{L}) \mathrm{Ca}^{2+}(\mathrm{mg} / \mathrm{L})$} & $\begin{array}{c}\mathrm{Ba}^{2+} \\
(\mathrm{mg} / \mathrm{L})\end{array}$ & $\begin{array}{c}\text { Sulphate } \\
\left(\mathrm{SO}_{4}^{2-}\right)(\mathrm{mg} / \mathrm{L})\end{array}$ & $\begin{array}{c}\text { Phosphate } \\
\left(\mathbf{P O}_{4}^{3-}\right)(\mathrm{mg} / \mathrm{L})\end{array}$ & $\begin{array}{c}\text { Cyanide } \\
\left(\mathrm{CN}^{-}\right)(\mathrm{mg} / \mathrm{L})\end{array}$ \\
\hline Agbor Obi & 0.27 & 1.45 & $\mathrm{BD}$ & 0.56 & 0.11 & $\mathrm{BD}$ \\
BB Agbor & 0.35 & 2.29 & $\mathrm{BD}$ & 0.73 & 0.13 & $\mathrm{BD}$ \\
BB Owa & 0.22 & 1.82 & $\mathrm{BD}$ & 0.42 & 0.07 & $\mathrm{BD}$ \\
Owa-Alero & 0.18 & 1.24 & $\mathrm{BD}$ & 0.55 & 0.07 & $\mathrm{BD}$ \\
Alihame & 0.25 & 1.30 & $\mathrm{BD}$ & 0.61 & 0.09 & $\mathrm{BD}$ \\
Range & $\mathbf{0 . 1 8 - 0 . 3 5}$ & $\mathbf{1 . 2 4 - 2 . 2 9}$ & $\mathrm{NA}$ & $\mathbf{0 . 4 2 - 0 . 7 3}$ & $\mathbf{0 . 0 7 - 0 . 1 3}$ & $\mathrm{NA}$ \\
Mean & $\mathbf{0 . 2 5}$ & $\mathbf{1 . 6 2}$ & $\mathrm{NA}$ & $\mathbf{0 . 5 7}$ & $\mathbf{0 . 0 9}$ & $\mathrm{NA}$ \\
WHO & $\mathbf{2 0 0}$ & $\mathbf{7 5}$ & $\mathbf{0 . 3}$ & $\mathbf{5 0 0}$ & - & $\mathbf{0 . 0 7}$ \\
\hline
\end{tabular}

BD: Below Detected Limit $<0.0001 \mathrm{mg} / \mathrm{L} ; \mathrm{NA}$ : Not Available.

Table 2. Percentage compositions of detected chemical parameters in the study area.

\begin{tabular}{cccccc}
\hline Sample Area & $\mathrm{Na}^{+}$ & $\mathrm{Ca}^{2+}$ & $\mathbf{S O}_{4}^{2-}$ & $\mathbf{P O}_{4}^{3-}$ & Total weight (\%) \\
\hline Agbor Obi & 21.3 & 17.9 & 19.5 & 23.4 & $\mathbf{8 2 . 1}$ \\
BB Agbor & 27.6 & 28.3 & 25.4 & 27.7 & 109.0 \\
BB Owa & 17.3 & 22.5 & 14.6 & 14.9 & 69.3 \\
Owa-Alero & 14.2 & 15.3 & 19.2 & 14.9 & 63.6 \\
Alihame & 19.7 & 16.1 & 21.3 & 19.2 & 76.3 \\
\hline
\end{tabular}


an individual's risk of hypertension, heart disease, and stroke [27] [28]. Therefore knowing that $\mathrm{Na}^{+}$interacts readily with available $\mathrm{Cl}^{-}$, (although low chloride values have been reported in a previous study in these same areas) [29] there may be need to caution inhabitants of these communities on the in-take of salt, since sodium ions play a crucial role in relation to increasing possibility and cases of hypertension. Meanwhile, the sodium contents of each sample area, as well as the mean value obtained for the study area are well below WHO guideline value.

\subsection{Calcium}

From Table 1 again, BB Agbor recorded $2.29 \mathrm{mg} / \mathrm{L},(28.3 \%$ of the total calcium content) the highest value for calcium of the five sampled areas. Next BB Owa with $1.82 \mathrm{mg} / \mathrm{L}$, and Owa Alero the lowest (1.24 mg/L), representing 22.5\% and $15.3 \%$ respectively. The average calcium ion concentration in the study area is $1.62 \mathrm{mg} / \mathrm{L}$.

Water is classified as "soft" if it contains between $0-60 \mathrm{mg} / \mathrm{L} \mathrm{CaCO}\left(\mathrm{Ca}^{2+}\right.$ ion); and "hard" if it has between $121-180 \mathrm{mg} / \mathrm{L} \mathrm{CaCO}_{3}$ [24] [30] [31]. It therefore implies that with a calcium concentration level of $1.62 \mathrm{mg} / \mathrm{L}$ in the study area, the groundwater under investigation is categorically "soft", being well within the range of "soft" water as classified above. The snag though, is that "soft water" leads to corrosion of pipes and tanks, and subsequently, elevated levels of heavy metals in drinking water supply using metallic materials for pipelines and storage tanks [32] which can result in wrong diagnosis of parameters responsible for corrosion. However, since groundwater is not usually stored for long periods in storage tanks and because plastics (polyvinyl chloride, PVC) pipes and tanks are used instead, the heavy metal contents will be expected to be unaffected and healthily low.

\subsection{Barium}

The detection of $\mathrm{Ba}^{2+}$ in drinking water is of very crucial significance as it causes hypertension, gastrointestinal disturbance and weakness of muscles in doses above $0.7 \mathrm{mg} / \mathrm{L}$ [31]. Fortunately, barium content in the study area is below detection limit in the water samples in all the sample areas.

\subsection{Sulphate}

Sulphates occur in groundwater from natural sources [31]. Boji-Boji Agbor had the highest sulphate value of $0.73 \mathrm{mg} / \mathrm{L}$ (25.4\%), followed by Alihame (0.61 $\mathrm{mg} / \mathrm{L}$ ) and Owa Alero (0.55 mg/L), 21.3\% and 19.2\% respectively. Boji-Boji Owa is however least in sulphate content with $0.42 \mathrm{mg} / \mathrm{L}(14.6 \%)$ recorded. An average of $0.57 \mathrm{mg} / \mathrm{L}$ sulphate content is reported for the groundwater in the study area. By interpretation, it means that the sulphate content of the study area is quite good, considering that as much as 100 and $250 \mathrm{mg} / \mathrm{L}$ for Nigeria [31] [33] are recommended as guideline values respectively. 


\subsection{Phosphate}

Phosphate like nitrate is majorly a component of fertilizers. Digestive problems can occur from extremely high levels of phosphate [34]. Phosphate content is highest in BB Agbor, followed closely by Agbor Obi with 0.13 (27.7\%) and 0.11 $\mathrm{mg} / \mathrm{L}$ (23.4\%) respectively. BB Owa and Owa Alero have the same phosphate value of $0.07 \mathrm{mg} / \mathrm{L}$ representing the least of all the sampled areas. This result indicates that the study area is not polluted with regards to phosphate and hence should be free of algal infestation and eutrophication of water reservoirs [35] [36]. The average phosphate content of the study area is $0.09 \mathrm{mg} / \mathrm{L}$ indicating the near absence of fertilizer-dependent agricultural activity.

\subsection{Cyanide}

Cyanide is acutely toxic [24], affecting both the thyroid and nervous systems. Cyanide occurs naturally in some food (cassava) but rarely found in drinking water. If at all, usually at extremely low concentrations.

From Table 1, it is observed that cyanide was below detection limit. Thus inferring that the groundwater may be cyanide-free, or its concentration is too low or insignificant to be detected by the instrument of analysis. Furthermore, the absence of industrial activity in the study area gives reasons to support these results, especially since cyanide is rarely found in drinking water except from industrial contamination particularly of surface water.

\subsection{Correlation Matrix}

Inter-metal relationships provide information on metal sources and pathways. Table 3 summarizes the correlation co-efficient of the parameters under study in the groundwater of the area. A strong correlation exists between sodium and calcium, and indeed sodium and all the other analytes. This strong sodium-calcium correlation suggests the existence of some form of sodium-calcium-double salts; possibly a combination of sodium-calcium sulphate or phosphate.

A value of 0.18 was obtained for the ratio of $\mathrm{Na}^{+} / \mathrm{Ca}^{2+}$, inferring a preponderance of $\mathrm{Ca}^{2+}$ (mean values of 0.25 and $1.62 \mathrm{mg} / \mathrm{L}$ for $\mathrm{Na}^{+}$and $\mathrm{Ca}^{2+}$ respectively as reported in Table 1), indicating a calcite-heavy cationic background. Furthermore, comparing the ratio of the mean concentrations of $\mathrm{PO}_{4}^{3-} / \mathrm{SO}_{4}^{2-}$ gives a

Table 3. Correlation matrix of the chemical species detected in the groundwater of the study area.

\begin{tabular}{ccccc}
\hline Parameter & $\mathrm{Na}^{+}$ & $\mathbf{C a}^{2+}$ & $\mathbf{S O}_{4}^{2-}$ & $\mathbf{P O}_{4}^{3-}$ \\
\hline $\mathrm{Na}^{+}$ & 1 & 0.758 & 0.761 & $0.954^{*}$ \\
$\mathbf{C a}^{2+}$ & 0.758 & 1 & 0.376 & 0.592 \\
$\mathbf{S O}_{4}^{2-}$ & 0.761 & 0.376 & 1 & 0.815 \\
$\mathbf{P O}_{4}^{3-}$ & $0.954^{*}$ & 0.592 & 0.815 & 1 \\
\hline
\end{tabular}

${ }^{*}$ Correlation is significant at the 0.05 level (2-tailed). 
value of 0.158 , implying a sulphate preponderant anionic background. Thereby suggesting a calcium sulphate-rich $\left[\mathrm{CaSO}_{4}\right]$ hydrogeologic environment.

Meanwhile correlation study shows very strong relationship between sodium with sulphate and phosphate, more especially between sodium and phosphate ( $r-0.954)$, but less for calcium with the same anions. These indicate the likelihood of the heavier presence of sulphate and phosphate of sodium $\left(\mathrm{Na}_{2} \mathrm{SO}_{4}\right.$ and $\mathrm{Na}_{3} \mathrm{PO}_{4}$ ) albeit, in trace amounts. These give further indication of the likelihood of a sodium-calcium phosphate $\left(\mathrm{NaCaPO}_{4}\right)$ double salt background. Although with a comparatively weaker correlation observed between $\mathrm{Ca}^{2+}$ and $\mathrm{SO}_{4}^{2-}$ ( $\mathrm{r}-0.376)$, the higher proportion of calcium and sulphate recorded in Table 1, and the values of the concentration ratios of $\mathrm{Na}^{+} / \mathrm{Ca}^{2+}(0.18)$ and $\mathrm{PO}_{4}^{3-} / \mathrm{SO}_{4}^{2-}$ (0.158) point at a predominantly calcium sulphate mineral composition for the study area. These generally present a geogenic picture of the study area in this respect.

\section{Conclusions}

Non-heavy metal ions of barium, calcium, and sodium, as well as sulphate, phosphate, and cyanide contents in groundwater of the Agbor/Owa town and immediate suburbs were studied in this exercise. Results obtained suggest that the groundwater of the area is calcium and sulphate rich, with a good mix of sulphates and phosphates of sodium, and less of calcium phosphate relatively. A strong possibility of sodium-calcium phosphate double salt also exists. All study sub-areas had significant amounts of sodium in their water samples. Three of these are up to the WHO daily intake limit of $0.25 \mathrm{mg} / \mathrm{L}$ and the other two just close. This portends a health risk vis a vis the role of sodium ion with incidences of hypertension in humans. Sodium is highest in the Agbor areas (Agbor Obi, BB Agbor, and Alihame) according to the results from the sample areas.

Average calcium content of the study area is higher than sodium's. This poses the economic problem of corrosion of metal pipelines and storage tanks, as well as, hardness of water which will require more soap to form lather. Happily though, the mean value for calcium is too low to be considered a serious economic threat in this sense.

Barium and cyanide were both undetected in all the sampled areas. This is apparently encouraging, considering the adverse health implications of both ions in drinking water source.

The highest concentrations of all the studied chemical parameters were obtained in BB Agbor followed by Agbor Obi, Alihame, BB Owa, and Owa Alero respectively.

Finally, since the concentrations of virtually all the studied parameters are quite below the maximum contaminant levels of the WHO we can conclude that the ground water is wholesome with respect to these chemicals species. However, concern still remains on the health implications of high sodium concentrations in many study-areas being up to and quite above daily threshold limits of 
the WHO. Secondly, it will be of better economic benefit for inhabitants of the area if pipelines and water storage tanks are of nonmetallic constituents so as to avoid corrosion, and a concomitant increase in heavy metals in drinking water.

\section{Acknowledgements}

We wish to appreciate the Tertiary Education Trust Fund (TETFund) of Nigeria for this wonderful privilege and opportunity to further of our research endeavours. Appreciation also goes to the Management of the College of Education, Agbor under whose auspices this Grant was offered for the enabling environment for academic growth and development. We also wish to thank individuals and research outfits whose experiences and resources were consulted in this exercise.

\section{References}

[1] Rim-Rukeh, A., Ikhifa, G.O. and Okokoyo, P.A. (2007) Physico-Chemical Characteris-Tics of Some Waters Used for Drinking and Domestic Purposes in the Niger Delta, Nigeria. Environmental Monitoring and Assessment, 128, 475-482. https://doi.org/10.1007/s10661-006-9340-4

[2] Ramesh, K. and Elango, L. (2014) Impact of Groundwater Quality from Industrial East Coastal Town, Southern India. International Journal of Engineering Research and Applications, 4, 346-354.

[3] Vanloon, G.W. and Duffy, S.J. (2005) The Hydrosphere. In: Environmental Chemistry: A Global Perspective, 2nd Edition, Oxford University Press, New York.

[4] Hedge, G.K. and Kale, Y.S. (1995) Quality of Lentic Waters of Dharwad District in North Karnataka. Indian Journal of Environmental Health, 37, 52-56. http://www.un.org/waterforlifedecade/quality.shtml

[5] Macdonald, A.M. and Calow, R.C. (2009) Developing Groundwater for Secure Rural Water Supplies in Africa. Desalination, 248, 546-556.

[6] World Health Organization (WHO) (2007) Water for Pharmaceutical Use. In: Quality Assurance of Pharmaceuticals: A Compendium of Guidelines and Related Materials, 2nd Edition, World Health Organization, Geneva.

[7] Mendie, U. (2005) The Nature of Water. In: The Theory and Practice of Clean Water Production for Domestic and Industrial Use, Lacto-Medals Publishers, Lagos.

[8] Vodela, J.K., Renden, J.A., Lenz, S.D., Mchel Henney, W.H. and Kemppainen, B.W. (1997) Drinking Water Contaminants. Poultry Science, 76, 1474-1492.

https://doi.org/10.1093/ps/76.11.1474

[9] Krishna, K.A. and Mohan, K.R. (2014) Risk Assessment of Heavy Metals and Their Source Distribution in Waters of a Contaminated Industrial Site. Environmental Science and Pollution Research, 21, 3653-3669. https://doi.org/10.1007/s11356-013-2359-5

[10] Mackey, R. (1990) Groundwater Quality. In: Thannah and Biswas, A.K., Eds., Environ-Mentally Sound Water Management, Oxford University Press, New York.

[11] Edmunds, W.M. and Smedley, P.L. (1996) Environmental Geochemistry and Health with Special Reference to Developing Countries. British Geological Survey, Wallingford.

[12] Australian Academy of Science. Underground Water-Key Text. 
http://www.science.org.au/nova/100/100key.html

[13] Rogers, N.R. (2002) Introduction to Environmental Analysis. John Wiley and Sons Ltd., New York.

[14] The Groundwater Foundation. What Is Groundwater? http://www.groundwater,org/gi/whatisgw,html

[15] Al-harbi, O.A., Hussain, G., Khan, M.M., Moallim, M.A. and Al-Sagaby, I.A. (2006) Evaluation of Groundwater Quality and Its Recharge by Isotopes and Solute Chemistry in Wadi Malal, Al-Madinah Al-Munawarah, Saudi Arabia. Pakistan Journal of Biological Sciences, 9, 260-269. https://doi.org/10.3923/pjbs.2006.260.269

[16] Marcovecchio, J.E., Botte, S.E. and Freije, R.H. (2007) Heavy Metals, Major Metals, Trace Elements. In: Nollet, L.M., Ed., Handbook of Water Analysis, 2nd Edition, CRC Press, London. https://doi.org/10.1201/9781420006315.ch11

[17] Odjugo, P.A.O. (2008) The Effect of Tillage Systems and Mulching on Soil Microclimate, Growth and Yield of Yellow Yam (Dioscora cayenensis) in Midwestern Nigeria. African Journal of Biotechnology, No. 24, 4500-4507.

[18] Avwunudiogba, A. (2000) A Comparative Analysis of Soil and Nutrient Losses on Maize Plant with Different Tillage Practices in Ikpoba River Basin of South-Western Nigeria. The Nigerian Geographical Journal, 3, 199-208.

[19] Burubai, W., Akor, A.J. and Lilly, M.T. (2007) Performance Evaluation of Septic System for High Water-Table Areas. American-Eurasian Journal of Scientific Research, 2, 112-116.

[20] Tomar, M. (1999) Quality Assessment of Water and Waste Water. CRC Press, London.

[21] Environmental Protection Authority (EPA) (2000) A Guide to the Sampling and Analysis of Waters, Waste Waters, Soils and Wastes. EPA.

[22] Patil, G.P. (2012) Composite Sampling. In: El-Shaarawi, A.H. and Piegorsch, W.W., Eds., Encyclopedia of Environmetrics, John Wiley \& Sons Ltd., Chichester.

[23] American Public Health Association (APHA) (2005) Standard Methods for the Examination of Water and Wastewater. 21st Edition, Washington DC.

[24] United Nations Children's Fund (UNICEF) (2008) Handbook on Water Quality. UNICEF, New York.

[25] Austgen, L. (2006) The Na+-K+-ATPase (Sodium Pump). http://www.vivo.colostate.edu/hbooks/molecules/sodium_pump.html

[26] Mayo Foundation for Medical Education and Research (MFMER) (2008) Sodium: Are You Getting Too Much? http://www.mayoclinic.com/health/sodium/NU002842

[27] Centers for Disease Control and Prevention (CDC) (2009) Most Americans Should Consume Less Sodium (1,500 mg/day or less). http://www.cdc.gov/Features/Sodium/

[28] Shaparenko, G. (2009) Sodium, Your Health, and Your Drinking Water. http://www.aquatechnology.net/frame43251.html

[29] Oyem, I.M., Oyem, H.H., Oyem, M.N., Usese, A.I., Ezenwali, D. and Obiwulu, E.N.O. (2015) An Investigation in to Groundwater Contaminations in Agbor and Owa Communities in Nigeria. Sacha Journal of Environmental Studies, 5, 28-35.

[30] Manta, D.S., Angelone, M., Bellanca, R., Neri, A. and Sprovieri, M. (2002) Heavy Metals in Urban Soils: A Case Study from the City of Palermo (Sicily), Italy. Science of the Total Environment, 300, 229-243.

[31] World Health Organization (WHO) (2008) Water for Health, WHO Guidelines for 
Drinking-Water Quality. WHO, Geneva.

[32] World Health Organization (WHO) (2009) Calcium and Magnesium in DrinkingWater: Public Health Significance. World Health Organization, Geneva. http://whqlibdoc.who.int/publications/2009/9789241563550_eng.pdf

[33] Nigeria Industrial Standard (NIS) (2007) Nigerian Standard for Drinking Water Quality. Standards Organization of Nigeria, Abuja.

[34] Kumar, M. and Puri, A. (2012) A Review of Permissible Limits of Drinking Water. Indian Journal of Occupational and Environmental Medicine, 16, 40-44.

[35] Ademoroti, C.M.A. (1996) Standard Methods for Water and Effluents Analysis. Foludex Press Ltd., Ibadan.

[36] Igbinosu, E.O. And Oko, A.I. (2009) Impact of Discharge Wastewater Effluents on the Physico-Chemical Qualities of a Receiving Watershed in a Typical Rural Community. International Journal of Environmental Science and Technology, 6, 175 182.

Submit or recommend next manuscript to SCIRP and we will provide best service for you:

Accepting pre-submission inquiries through Email, Facebook, LinkedIn, Twitter, etc. A wide selection of journals (inclusive of 9 subjects, more than 200 journals)

Providing 24-hour high-quality service

User-friendly online submission system

Fair and swift peer-review system

Efficient typesetting and proofreading procedure

Display of the result of downloads and visits, as well as the number of cited articles

Maximum dissemination of your research work

Submit your manuscript at: http://papersubmission.scirp.org/

Or contact gep@scirp.org 